\title{
Solar Thermal Design: Research, Design and Installation of a Solar Hot Water System for Redwood National Park
}

\author{
Andrew Sorter, Kelly Miess, Richard Engel, and Angelique Sorensen \\ Environmental Resources Engineering \\ Humboldt State University \\ Arcata, California 95521 USA
}

Received:January 6, 2003 Accepted: February 3, 2003

\begin{abstract}
This paper details the research, design and installation of the solar thermal water-heating project at the Redwood Information Center (RIC) in Orick, California, USA. The project was completed as part of the University-National Park Energy Partnership Program (UNPEPP) for the summer of 2002.
\end{abstract}

\section{INTRODUCTION}

Since 1997, University-National Park Energy Partnership Program (UNPEPP) has partnered undergraduate university students and faculty with National Park Service personnel to research and develop sustainable energy use practices in the National Parks. Projects focus on reducing fossil fuel use in accordance with the National Park's Green Energy Parks program. This association provides technical assistance to the Parks while offering valuable, real-world research and design experiences for undergraduate students in science and engineering.

Together Humboldt State University (HSU), Schatz Energy Research Center (SERC) and Redwood National Park selected the Redwood Information Center (RIC) at Redwood National Park (Orick, CA) as a project site for the UNPEPP 2002 partnership. HSU provided two student interns from the Environmental Resources Engineering department who were advised by SERC engineers and Redwood National Park staff in the disciplines necessary to complete the project. The project's objective was to design and install a solar water heating system to replace the electric water heater that was then in use at RIC. Working through SERC, we, the interns, conducted an on-site investigation that included solar availability, water usage and energy consumption data collection and analysis. We used site data, research on contemporary solar water heating technologies, and an economic analysis to design an appropriate solar water heating system for RIC. With technical and design assistance from SERC and construction and installation expertise from Redwood National Park, we successfully researched, designed and installed the water heating system. Since it was installed on August 7, 2002, the system has been providing nearly all of the hot water used at RIC.

\section{DESIGN CONSIDERATIONS}

Due to its high specific heat, heating water is extremely energy intensive. Water heating is second only to space heating in the amount of domestic energy consumed in developed countries. Water heating is estimated to account for $25 \%$ of the total energy consumption for a family of four living in the U.S. [1]. Interestingly, water heating is one of the oldest and simplest solar energy applications. At their most basic level, solar thermal water heating technologies collect and store the solar energy using a thermal fluid. Systems range from very simple and inexpensive batch 
heaters that consist of one tank that both collects solar energy and stores heated water, to complex systems made with sophisticated materials and highly engineered components [2].

$\mathrm{RIC}$ is the main visitor center in the southern extent of Redwood National Park, located on the west side of Highway 101 several hundred yards from the Pacific Ocean and just south of Orick, California. The center serves approximately 1,000 visitors per day from Memorial Day to Labor Day. Until recently, an 18-year old water heater served the visitor center. Both patrons and employees complained of tepid hot water delivery. Our assignment was to replace the existing electric water heater with a solar hot water system that would supply reliable hot water year round.

To begin our research into solar thermal water heating applications, we familiarized ourselves with various types of systems. After researching the major classes of current solar water heating technology, we focused our attention on active, indirect systems. Active systems are different from passive systems in that they employ pumps, rather than natural heat convection currents, to move the thermal fluid throughout the system. Indirect systems are distinguished from direct systems in that they use a thermal fluid other than water to collect solar energy. The heated thermal fluid is then directed through a heat exchange appliance to heat water.

We chose an active, indirect system for two reasons. First, active systems operate at much higher thermal conversion efficiencies than indirect systems. Furthermore, indirect technology was appropriate for our site because the chance of system damage due to the freezing of the thermal fluid was eliminated with the use of a non-freezing propylene glycol/water mixture. This consideration was important because we wanted the system to operate year-round without burdening Park staff with the extra maintenance that would arise with the area's occasional freezing conditions.

After deciding on the active, indirect system, our next consideration was the style of collection appliance. There are three basic collector types. 1) The batch collector is a simple tank, sized to store enough water for one day. The tank is painted a dark color to maximize solar absorption and placed in an insulated box to retain heat. 2) The flat plate collector is a shallow, usually $4 \mathrm{ft}$ by 8 $\mathrm{ft}$ [1.22 $\mathrm{m}$ by $2.44 \mathrm{~m}$ ] insulated box with a glass cover. Running through the box are a series of copper pipes connected by dark absorber plates that maximize solar absorption. The thermal fluid is heated as it moves through the pipes. 3) The evacuated tube collector is an improvement on the flat plate design. The evacuated tube collector operates at a higher efficiency because a vacuum with the glass tubes eliminates conductive heat losses and the cylindrical tubes are always at the most advantageous perpendicular angle to the sun.

Batch collectors were not seriously considered for this project due to their low efficiencies. Evacuated tube technology was attractive for both efficiency and their reputation for high output in limited solar environments like the often-foggy coastal RIC location. However, after careful consideration of the three options, we chose to configure our system with flat plate collectors, which are discussed later in the paper.

\section{ASSESSING SOLAR RESOURCE AND HOT WATER LOAD}

Hot water demand, solar availability or insolation, and the availability of an unobstructed solar window at the collector site are the three main factors for determining the viability of operating a solar water heating system at a specific location. We estimated the hot water demand at RIC by measuring the energy use of the existing electric water heater. We placed a current sensor around one leg of the electric wire of the existing water heater circuit. We then connected the sensor to a data logger set to record current measurements at 30-second intervals. From this data, we established a profile of the use cycle of the water heater. The current data were measured over a period of two weeks (31 May to 14 June 2002).

These dates correspond to a time of peak park visitation. Therefore, this time period was a good indicator of peak hot water usage. This estimation assumed that all energy used by the electric water heater was being used to heat water for immediate use and did not include stand-by losses that are due to heating water when it is not 


\section{RIC Monthly Energy Consumption Summer 2002}

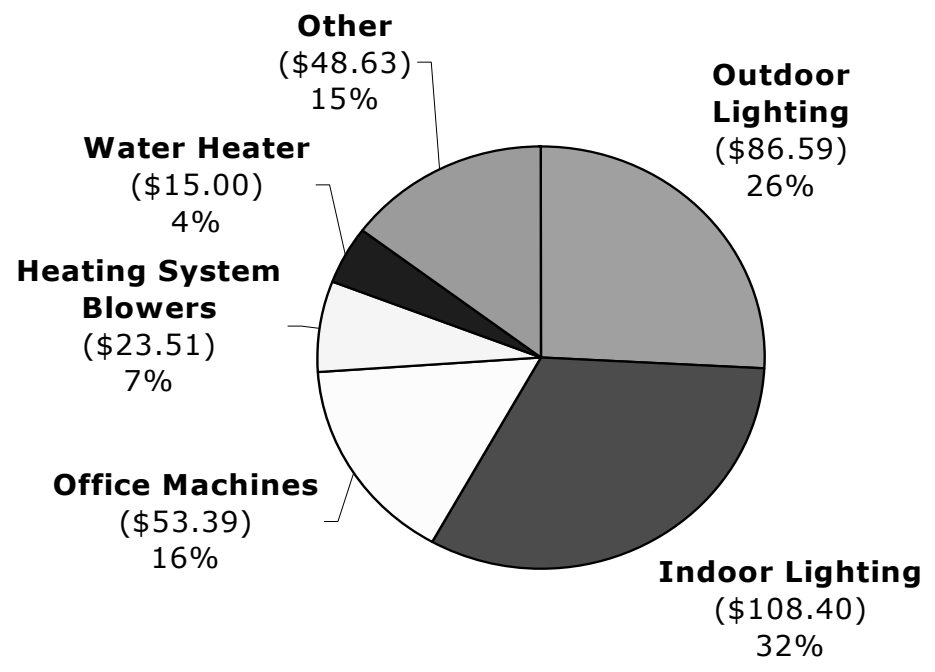

Figure 1. Results of the RIC energy audit.

needed. Thus, our estimate was somewhat higher than the actual hot water usage. We also monitored the gross electricity use for RIC over the same period by recording daily energy meter readings. Comparing the measured water heater load to the gross electricity use allowed us to view the energy usage of the water heater as a percentage of RIC's total energy consumption. Our results indicated that the energy demand of the existing electric water heater was about $4.7 \mathrm{kWh}$ per day, which is $4 \%$ of the total energy usage at RIC. This amount of energy use is equivalent to a $30-40$ gallon/per day [0.11 to $0.15 \mathrm{~m}^{3}$ per day] hot water demand. This figure was lower than we had expected, leading us to conduct an energy audit of the RIC building to determine a) whether the measured energy consumption of the water heater was accurate, and b) where the majority of the energy was being consumed at RIC.

We conducted a complete energy audit to provide a comprehensive accounting of electrical usage at RIC. The audit consisted of a walk-through accounting of all visible electrical loads. When possible, we obtained wattage ratings for specific appliance/electronic devices from manufacturer's specification labels. Where labels were not visible, we measured power requirements directly by using an instantaneous wattmeter or current sensors. Where this was impractical, we obtained wattages through manufacturers' websites or used generic wattage ratings for common electronics that we obtained from the Oak Ridge National Laboratory's Energy Efficiency and Renewable Energy Program [3]. Specific appliance use estimates were obtained from RIC staff interviews and hardwired appliance timers. After collecting this data, we categorized and subtotaled the apparent electrical usage. Total monthly energy use accounted for in the energy audit was $3,059 \mathrm{kWh}$. This was comparable to the average monthly usage calculated from RIC energy bills provided by Park staff (Table 1). This indicated that our audit was a complete accounting of the energy use at RIC. The audit also confirmed that the existing electric water heater was responsible for only $4 \%$ of the total energy use at RIC (Figure 1).

As shown in Figure 1, the majority of energy consumed at RIC is used for indoor 
and outdoor lighting. By comparison, the water heater's contribution to the overall electrical load is very small. Our audit led us to conclude that although replacing the electric water heater would decrease energy consumption at RIC, analyzing and addressing the power requirements of the lighting systems could yield even more significant energy savings. Potential design improvements might include daylighting, self-dimming ballasts triggered from photocells, and better seasonal timer management. These recommendations were made to Park staff and may provide a basis for a future UNPEPP project.

After completing the energy audit, our next step was to evaluate the solar window and the amount of insolation available at the installation site. The Solar Pathfinder ${ }^{\circledR}$ is a tool that allows the user to view any obstructions in an entire year's solar window in one image. We used a Solar Pathfinder $®$ to confirm that RIC had a completely unobstructed solar window throughout the year. To measure the solar insolation, a device called a pyranometer is used. We installed a pyranometer in the northwest corner of the RIC service yard. We logged pyranometer data at 10-second intervals for two weeks. Because we had a very short window for recording site-specific data, we also obtained average monthly insolation figures for nearby Arcata, California, from the National Renewable Energy Laboratory (NREL) [4]. NREL data provides monthly average insolation levels for a typical year based on a 30-year average. By comparing the measured data to the NREL data, we established that the NREL information was consistent with the conditions we would expect at RIC.

Once we determined the insolation levels, we calculated the necessary collector area needed to supply the hot water demand. The orientations used in the calculation of collection area were based on two possible configurations. Ideally, collectors are mounted on a south-facing roof. Because the roof of the RIC building is oriented east/west, our configuration options were limited to a flush mounting on the $18^{\circ}$ east-facing roof or a raised southfacing orientation tilted off of the east-facing

\begin{tabular}{|l|c|c|}
\hline \multicolumn{1}{|c|}{ Month } & $\begin{array}{c}\text { Charge } \\
\text { (US \$) }\end{array}$ & $\begin{array}{c}\text { Total } \\
\text { Energy } \\
\text { Cost } \\
\text { (kWh) }\end{array}$ \\
\hline January & 449.29 & 3370 \\
\hline February & 353.41 & 3420 \\
\hline March & 346.6 & 3310 \\
\hline April & 329.24 & 3130 \\
\hline May & 333.31 & 3170 \\
\hline June & 452.36 & 3070 \\
\hline July & 589.55 & 2820 \\
\hline August & 484.77 & 2900 \\
\hline September & 419.11 & 2500 \\
\hline October & 445.37 & 2660 \\
\hline November & 476.57 & 2850 \\
\hline December & 394.1 & 2840 \\
\hline \multicolumn{2}{|l|}{ Average Monthly kWh } & $\mathbf{3 0 0 3}$ \\
\hline Average Monthly Charge & $\mathbf{\$ 4 2 3}$ \\
\hline
\end{tabular}

Table 1. A summary of the 2001 calendar year energy bills for the Redwood Information Center. Costs are in US dollars and energy usage is in kilowatt-hours (kWh).

roof at a $41^{\circ}$ angle (equal to latitude at RIC). These configurations are shown in Figure 2.

In order to reconcile differences in solar insolation levels throughout the year, system cost and collector size should be balanced. For example, if a system were designed to supply $100 \%$ of the hot water needed in the colder and darker winter months, the number of collectors required would render the system cost prohibitive and prone to serious overheating in the summer. In contrast, if a system were designed considering only summer insolation levels, winter performance would be severely hampered. Therefore, an ideal solar water heating system is typically designed to supply $70-80 \%$ of the total yearly water heating load [5]. These systems tend to supply all of the water needed in summer months but require some supplemental heating the remainder of the year.

With the insolation, loading and solar availability known, we calculated the optimal collector area for the two possible orientations established for the RIC site. 

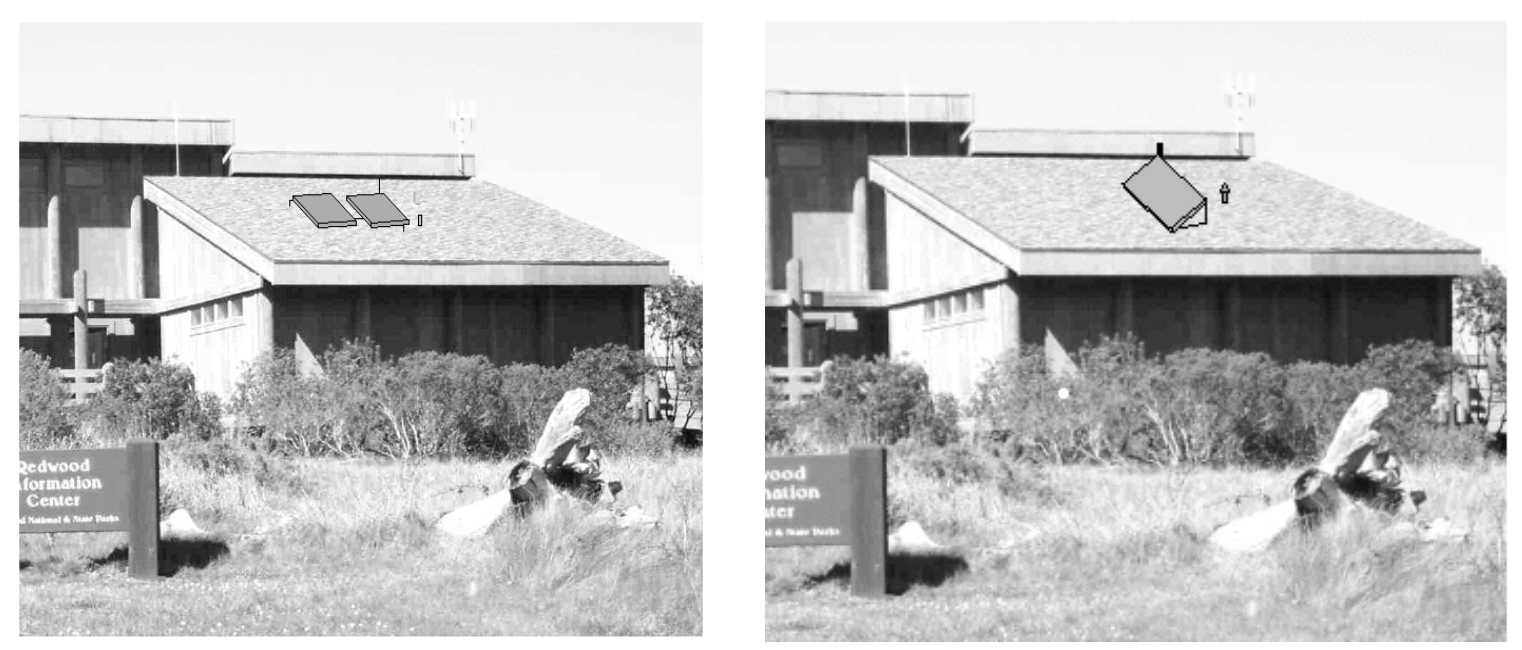

Figure 2. Renderings of two collector configurations, pictured on the roof of a section of the RIC.

The equation for determining collector area is

$$
A=\left(\frac{\text { Load }}{\eta \cdot \mathrm{I}}\right) \cdot(\% \text { Solar Availability })
$$

Here A is the collector's area in square feet, Load is the energy per day (in Btu/day) to heat needed water to the service temperature, $\eta$ is a measure of the collector's efficiency, I is the average monthly insolation in $\mathrm{Btu} / \mathrm{ft}^{2} /$ day, and $\%$ Solar Availability equals the percent of daily insolation available.

We used this equation to derive square footage figures for both orientations for each month of the year. We used a conservative load of 50 gallons $\left[0.18 \mathrm{~m}^{3}\right]$ per day boosted $80^{\circ}$ Fahrenheit. Collector efficiency can be found on manufacturer's specification sheets or from the Solar Rating and Certification Corporation [6]. We used an efficiency of 0.45 for all our calculations, which was an average of the efficiencies of the brands we were recommending. Insolation came from the NREL data. Finally, due to our unobstructed solar window, solar availability was $100 \%$.

We calculated that the square footage requirements in October gave us the necessary $70-80 \%$ of yearly hot water load. The following is a sample calculation for the month of October for a $41^{\circ}$ south orientation:

$$
\begin{aligned}
\text { Load } & =\left(50 \frac{\text { gal }}{\text { day }}\right)\left(8.34 \frac{\mathrm{lb}}{\text { gal }}\right)\left(80^{\circ} \mathrm{F} \frac{\mathrm{Btu}}{\mathrm{lb}^{0} \mathrm{~F}}\right) \\
& =33,360 \frac{\mathrm{Btu}}{\text { day }}
\end{aligned}
$$

so that

$$
\mathrm{A}=\left(\frac{33,360 \frac{\mathrm{Btu}}{\mathrm{day}}}{.45 * 2000 \frac{\mathrm{Btu}}{\mathrm{ft}^{2} \text { day }}}\right)=37.1 \mathrm{ft}^{2}
$$

As shown in the above calculation, we determined that the first configuration, consisting of a south orientation tilted $41^{\circ}$ from horizontal, required $37 \mathrm{ft}^{2}\left[3.44 \mathrm{~m}^{2}\right]$ of collector area, so one standard sized 4'x10' collector would be adequate. We calculated that the second configuration, consisting of an east-facing, flush-mounted collector, required approximately $65 \mathrm{ft}^{2}\left[6.04 \mathrm{~m}^{2}\right]$ of collector area, so two standard sized $4 \mathrm{ft} \times 8$ $\mathrm{ft}[1.22 \mathrm{~m}$ by $2.44 \mathrm{~m}$ ] collectors would be necessary.

\section{DESIGN RECOMMENDATION}

Our final design recommendation was developed based on our initial research, acquired site-specific data, data analysis and consultation with Park staff. From this information, we recommended an active, 
Redwood Information Center

Solar Water Heating System Schematic
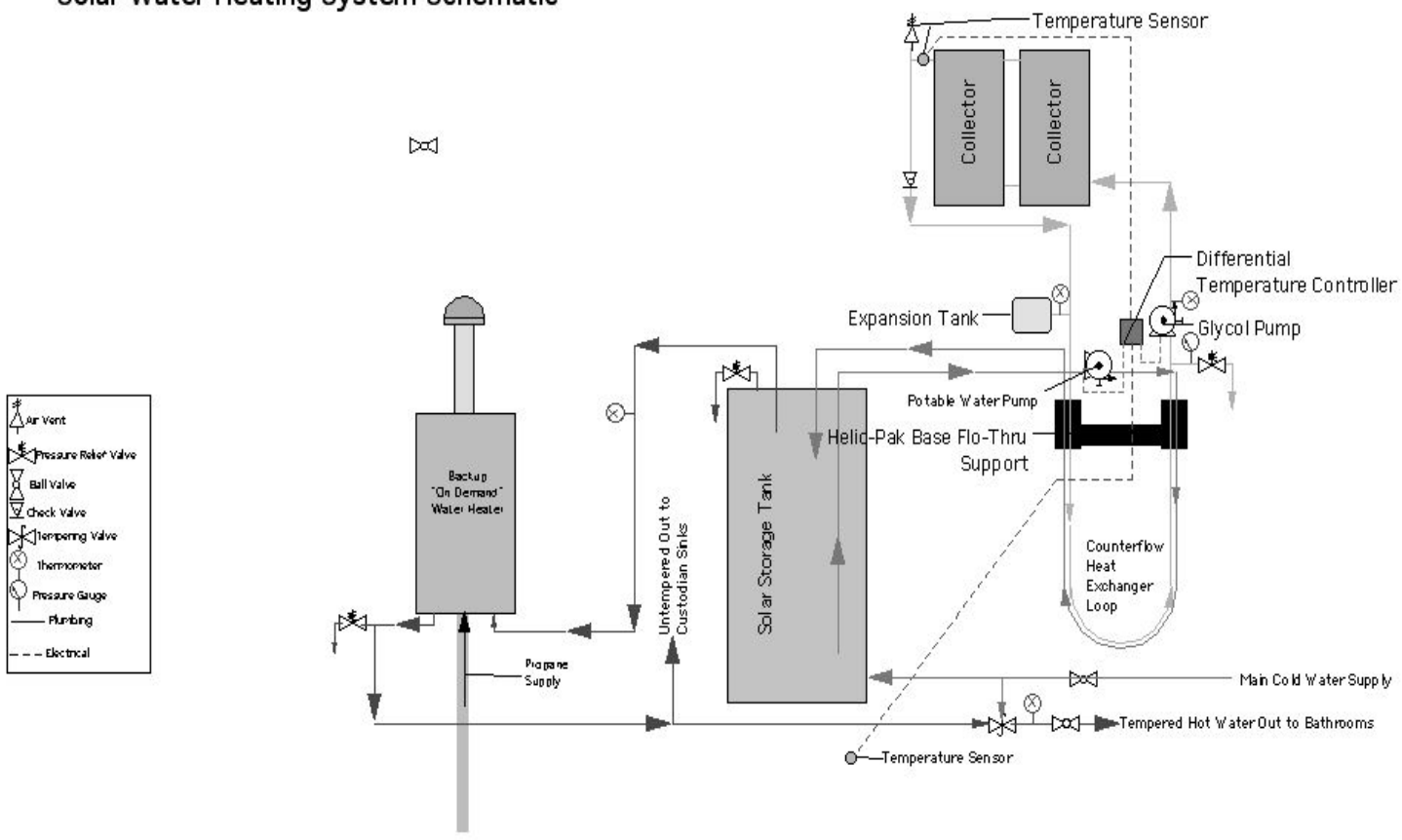

Figure 3. Schematic of the solar hot water system at the RIC.

indirect system as the most appropriate system for this installation. The main factors that influenced this decision were that the RIC site would have limited winter solar availability because of its foggy, coastal location, and that the potential for freezing conditions existed at the installation site. Indirect systems provide freeze protection through the use of a propylene glycol-water mixture working fluid. Active systems also operate at higher efficiencies and are therefore better suited for the somewhat limited solar conditions at RIC. We selected a flash or "on demand" propanefired water heater as a backup for the solar water heating system. A schematic of the proposed system can be seen in Figure 3.

The flash water heater we specified was an Aquastar 125-LPS. This model is designed to operate with a solar hot water system. The unit has sensors that allow it to determine the inlet water temperature and add only the amount of heat needed to boost water temperatures to the desired service temperature. If the inlet water temperature is at or above the desired service temperature, as it is in the summer, the burner is not activated, and the water passes through the unit with no further heating.

We provided the National Park Service with cost estimates for the two recommended system configurations from two manufacturers and several suppliers. After considering all options, Park staff decided that the flush mounted configuration was more desirable (even though it required twice the collector area of the "tilt mount" configuration) because they felt that a collector tilted off of the roof would negatively impact the aesthetics of the RIC building. The Park staff chose the Heliodyne brand, Heliopak AC-16 system, an American Water Heater Co. solar storage tank, and an Aquastar 125B-LPS back-up heater. The Heliopak AC-16 consists of the following components: two flat panel collectors, a counter flow heat exchanger, two circulating 


\begin{tabular}{|c|c|c|c|c|}
\hline Item & $\begin{array}{l}\text { Electric } \\
\text { Water } \\
\text { Heater }\end{array}$ & $\begin{array}{l}\text { Flash } \\
\text { Water } \\
\text { Heater }\end{array}$ & $\begin{array}{c}\text { Solar Flush Mount } \\
\text { 2-panel \& Flash } \\
\text { Heater }\end{array}$ & $\begin{array}{c}\text { Solar Tilt Mount 1- } \\
\text { Panel \& Flash } \\
\text { Heater }\end{array}$ \\
\hline Capital Equipment & $\$ 280$ & $\$ 1,100$ & $\$ 5,000$ & $\$ 4,300$ \\
\hline Operation and Maintenance & & & & \\
\hline Labor & $\$ 1,800$ & $\$ 1,900$ & $\$ 2,300$ & $\$ 2,300$ \\
\hline Materials & $\$ 0$ & $\$ 100$ & $\$ 100$ & $\$ 100$ \\
\hline Energy Costs & & & & \\
\hline Electricity & $\$ 5,900$ & & & \\
\hline Propane & & $\$ 4,300$ & $\$ 1,300$ & $\$ 1,300$ \\
\hline Repair and Replacement & $\$ 230$ & $\$ 100$ & $\$ 250$ & $\$ 250$ \\
\hline Salvage & $\$ 30$ & $\$ 110$ & $\$ 500$ & $\$ 430$ \\
\hline Total Life Cycle Cost & $\$ 8,180$ & $\$ 7,390$ & $\$ 8,450$ & $\$ 7,820$ \\
\hline
\end{tabular}

Table 2. Summary of a 25-year life cycle cost analysis (all values are in US dollars).

pumps, an expansion tank, five gallons [0.02 $\mathrm{m}^{3}$ ] of propylene glycol and miscellaneous small fittings.

\section{ECONOMIC ANALYSIS}

As a check on the economic feasibility of this project, we performed a life cycle cost analysis on four system alternatives (Table 2) comparing each system's cost over 25 years, the expected lifetime of a solar hot water system. The economic analysis was performed using the Sandia National Laboratories' present value method [7]. As a baseline comparison, the first alternative analyzed was a simple replacement of the existing electric water heater. The second alternative consisted of a flash hot water heater only. The remaining two systems considered were the two configurations we recommended to the Park, both solar systems with flash water heaters as a backup. One solar system was the one designed for flush mounting on the eastfacing roof. It required two $4 \mathrm{ft}$ by $8 \mathrm{ft}[1.22$ $\mathrm{m}$ by $2.44 \mathrm{~m}$ ] collectors. The other solar system was designed for south-facing, latitudinal tilt mounting and consisted of one
$4 \mathrm{ft}$ by $10 \mathrm{ft}[1.22 \mathrm{~m}$ by $3.05 \mathrm{~m}$ ] collector. In all other respects, the two solar systems were identical.

Our expectation was that, on an economic basis, the electric and the flash water heaters would outperform the solar options due to high initial capital equipment costs for the solar systems. We were surprised, then, to see that the life cycle cost analysis indicated that all four configurations had similar life cycle costs. The solar options require quite high initial capital equipment outlays but virtually no yearly energy costs. The electric and flash water heaters cost very little to install. Yet, their yearly energy consumption puts their lifetime costs in the same range as the solar options. As an additional advantage, the solar system we installed protects the Park from the potential of escalating energy costs.

Actual costs of the main components and incidental plumbing/ construction supplies can be seen in Table 3. The final cost of the system was just under our original estimate of $\$ 5,000$. 


\begin{tabular}{|l|l|c|c|}
\hline \multicolumn{1}{|c|}{ Item } & Cost Per Unit & $\begin{array}{c}\text { Number of } \\
\text { Units }\end{array}$ & Total Cost \\
\hline HELIOPAK W/ (2) 4 ft X 8 ft COLLECTORS & $\$ 2,839.00$ & 1 & $\$ 2,839.00$ \\
\hline HELIODYNE CAL CODE KIT & $\$ 105.00$ & 1 & $\$ 105.00$ \\
\hline 80 GALLON ${ }^{*}$ TANK W/ HEAT EXCHANGER & $\$ 619.00$ & 1 & $\$ 619.00$ \\
\hline ON-DEMAND WATER HEATER & $\$ 599.00$ & 1 & $\$ 599.00$ \\
\hline $3 / 4$ inch ${ }^{* *}$ TYPE M COPPER PIPING & $\$ 0.75$ & 60 & $\$ 45.00$ \\
\hline $3 / 4$ inch COPPER FITTINGS & $\$ 0.35$ & 100 & $\$ 35.00$ \\
\hline $3 / 4$ inch GALVANIZED PIPING & $\$ 0.72$ & 30 & $\$ 21.60$ \\
\hline $3 / 4$ inch GALVANIZED FITTINGS & $\$ 0.35$ & 25 & $\$ 8.75$ \\
\hline 5 inch TYPE B VENT PIPING & $\$ 3.46$ & 11 & $\$ 38.06$ \\
\hline 5 inch TYPE B VENT FITTINGS & $\$ 11.69$ & 3 & $\$ 35.07$ \\
\hline $3 / 4$ inch FOAM INSULATION & $\$ 0.30$ & 60 & $\$ 18.00$ \\
\hline CRATING AND SHIPPING & $\$ 250.00$ & 1 & $\$ 250.00$ \\
\hline MISC. SMALL PARTS & & & $\$ 200.00$ \\
\hline TOTAL & & & $\$ 4.813 .48$ \\
\hline
\end{tabular}

Table 3. Actual System Installation Cost Breakdown (in US dollars). ${ }^{*}$ One US gallon equals $0.03785 \mathrm{~m}^{3}$. ${ }^{* *}$ One inch equals $2.54 \mathrm{~cm}$.

VI. CONCLUSION

Since its August 7, 2002, installation, the solar water heating system designed and installed for the RIC has been providing nearly all of the hot water being used at the facility. Temperature sensors have been installed in key locations throughout the system, and a pyranometer has been installed in the plane of the flat plate collectors. These instruments are connected to data logging equipment, and these data will be used to create a profile of the general operation and performance of the system over the next year.

The UNPEPP 2002 Redwood Information Center Solar Water Heating
Project offered Schatz interns the opportunity to take an engineering project from the initial research and design stages to the actual hands-on installation. During this project we acquired and applied a broad range of applicable engineering skills, such as data acquisition and analysis, economic analysis, oral presentations, interpretive signage design, as well as all of the construction and plumbing activities associated with the system installation. With the energy expertise offered by the engineering staff of the Schatz Energy Research Center and the construction knowledge shared by Park staff, we were able to cultivate both the theoretical and practical skills needed to complete 
renewable energy project design and installation.

\section{REFERENCES}

1. Sheffer and Lau, "Solar Water Heating in Rural Pennsylvania," Solar Today. January/February 1994.

2. Lunde, Peter J., Solar Thermal Engineering- Space Heating and Hot Water Systems (John Wiley and Sons, New York, New York, USA, 1980).

3. Oak Ridge National Laboratory. Energy Efficiency and Renewable Energy Program. Online Posting. Accessed 30 December 2002. http://www.ornl.gov/ ORNL/Energy_Eff/Energy_Eff.html

4. National Renewable Energy Laboratory. Renewable Resource Data Center. Online Posting. Accessed 22 November 2002. http://rredc.nrel.gov/solar/old_data /bluebook/data/24283.SBF
5. James Leckie, Gilbert Masters, Harry Whitehouse, and Lillian Young, More Other Homes and Garbage: Designs for Self-Sufficient Living. (Sierra Club Books, San Francisco, 1981)

6. Solar Rating and Certification Corporation. Summary of SRCC Certified Solar Collectors and Water Heating Systems. July 2002. Online Posting. Accessed 6 January 2003.

http://www.solar-rating.org/summary/ dirsum_20020730.pdf

7. Sandia National Laboratories. Stand Alone Photovoltaic Systems-A Handbook of Recommended Design Practices. (National Technical Information Service, Springfield, Virginia, USA, 1995). 


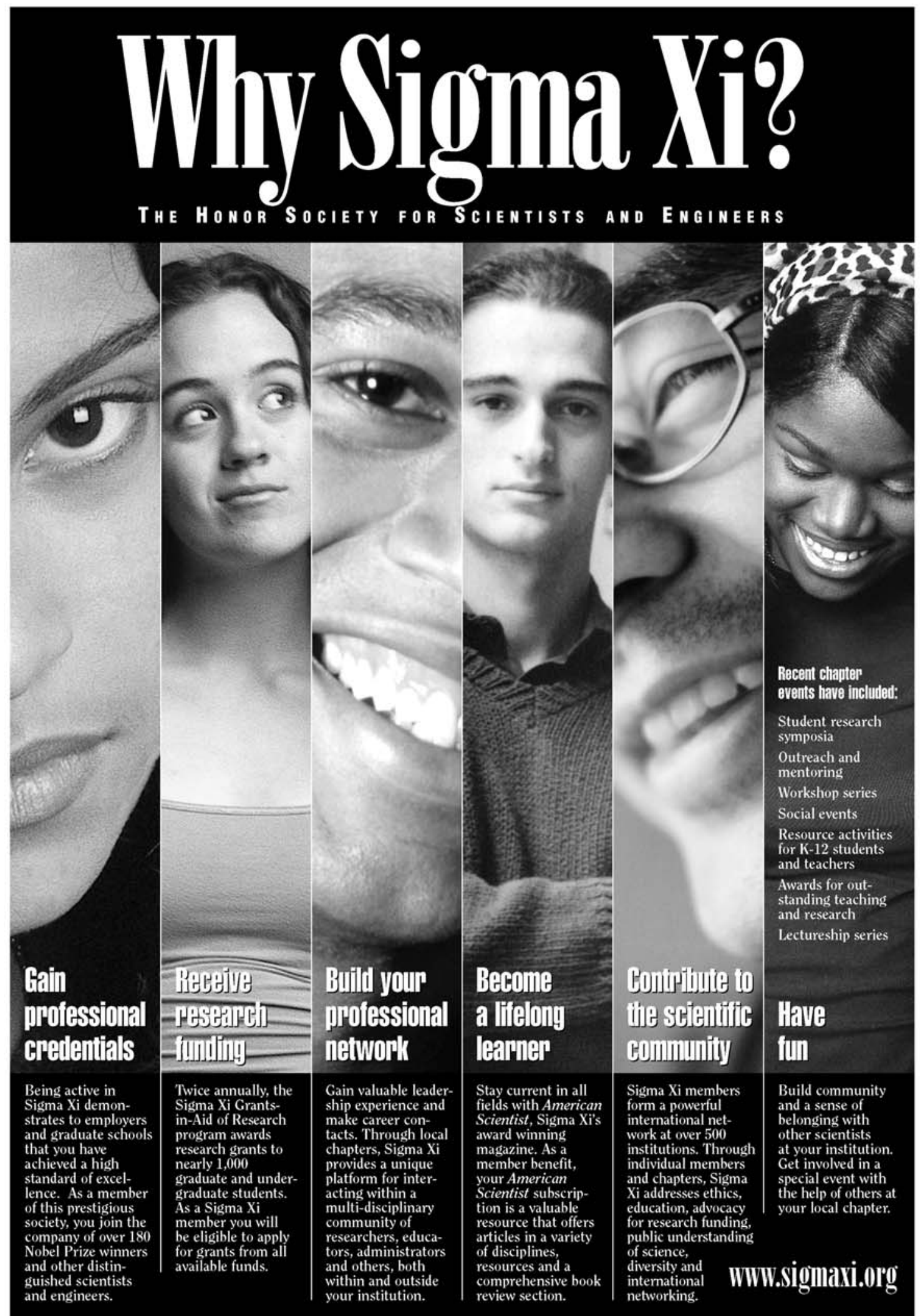

Sigma Xi, The Scientific Research Society • 88 Alexander Drive • P.O. Box 13975 • Research Triangle Park, NC 27708 • 818-549-4691 • 800-243-6534 